\title{
Antibiotic Susceptibility of Shiga Toxin Producing E. coli O157:H7 Isolated from Different Water Sources
}

\author{
Einas H. El-Shatoury ${ }^{2}$, M. Azab El-Leithy ${ }^{1, *}$, Mohamed A. Abou-Zeid ${ }^{2}$, Gamila E. El-Taweel ${ }^{1}$ and \\ Waled Morsy El-Senousy ${ }^{1}$
}

\author{
${ }^{I}$ Water Pollution Research Department, Environmental Research Division, National Research Centre, Dokki, Giza, \\ 12622, Egypt; \\ ${ }^{2}$ Microbiology Department, Faculty of Science, Ain Shams University. El- Khalifa El-Mamon St., Abbassia, Cairo, \\ 11566, Egypt
}

\begin{abstract}
Nowadays the extensive use of antibiotics for the treatment of humans and warm blooded animals has influenced the frequency and spread of antibiotic resistant $E$. coli $\mathrm{O} 157: \mathrm{H} 7$ in different aqueous sources. Thus, the main aim of this study was to evaluate the antibiotic susceptibilities of $E$. coli $\mathrm{O} 157: \mathrm{H} 7$ isolated from different water sources and establish a correlation between the presence of virulence genes of $E$. coli $\mathrm{O} 157: \mathrm{H} 7$ with the resistance to six antibiotic groups (amoxicillin, cefixime, ciprofloxacin, tetracycline, clarithromycin and streptomycin) extensively used in Egypt. To achieve this aim 44 suspect $E$. coli $\mathrm{O} 157: \mathrm{H} 7$ isolates were confirmed by biochemical tests and were characterized for six virulence genes: $f l i C$, stxl, stx2, eae, $r f b E$ and $h l y A$ using multiplex PCR. All E. coli O157:H7 isolates carrying three $(s t x 2$, eae and $r f b E$ ) or more virulence genes were resistant to amoxicillin and $77 \%$ were resistant to clarithomycin. In conclusion, it appears that the environmental E. coli $\mathrm{O} 157: \mathrm{H} 7$ strains develop strategies for antibiotic resistance more than reference strains.
\end{abstract}

Keywords: Antibiotic resistance, E. coli $\mathrm{O} 157: \mathrm{H} 7$, shiga toxins, water.

\section{INTRODUCTION}

E. coli $\mathrm{O} 157: \mathrm{H} 7$ causes a wide spectrum of human diseases, including bloody and non-bloody diarrhea, hemorrhagic colitis (HC), occasional kidney failure and hemolytic uremic syndrome (HUS) and E. coli O157 contamination of drinking, surface and recreational water has emerged as an important cause of human disease [1,2]. There is a varying level of antibiotic resistance among E. coli $\mathrm{O} 157: \mathrm{H} 7$ isolates. Some E. coli $\mathrm{O} 157: \mathrm{H} 7$ isolates have resistance to one or more antibiotics whereas others are multidrug resistant [3]. Schroeder et al. [4] focused on isolates from cattle, humans, swine, and farms. Some evidence suggests that the selective pressure imposed on livestock enteric bacteria by subtherapeutic antibiotic use sets the stage for the type of genetic mutations that are required to turn harmless E. coli into toxin-producing, dangerous serotypes [5].

It is known that multiple antibiotic resistance genes sometimes move from one bacterium to others via plasmids. The genes triggering the production of Shiga-like toxins by certain E. coli serotypes may move in the same way. The role and impact of antibiotic use in triggering this process are not understood and is subject to active debate [4]. Solomakos et al. [6] found that all of E. coli O157:H7 isolates were

*Address correspondence to this author at the Water Pollution Research Department, Environmental Research Division, National Research Centre, Dokki, Giza, 12622, Egypt; Tel: (+2) 01225110975 ;

E-mail:mohamedazabr@yahoo.com resistant to ampicillin, an antibiotic used in human medicine for the treatment of coliform infections, and all but one isolate were also resistant to streptomycin. Also, tetracycline was found to be the most inhibitory antimicrobial in terms of the number of isolates that were inhibited (27 isolates), followed by gentamicin (26 isolates) and cefuroxime (22 isolates). Moreover, Olatoye [7] found that $100 \%$ of the E. coli O157:H7 isolates were resistant to one or more antibiotics. Tetracycline resistance was the highest (in $91.4 \%$ of the isolates), while $72.9 \%$ of the isolates were resistant to nitrofurantoin and chloramphenicol, $65.7 \%$ to cefuroxime, $44.3 \%$ to cotrimoxazole, $35.7 \%$ to nalidixic acid, and $11.4 \%$ to gentamicin. The main aim of this study was to determine the antibiotic resistance of E. coli O157:H7 isolated from different water sources, and besides that, finding if there is correlation between the presence of E. coli $0157: \mathrm{H} 7$ virulence genes and antibiotic resistance.

\section{MATERIALS AND METHODS}

\section{E. coli O157:H7 Isolates}

E. coli $\mathrm{O} 157: \mathrm{H} 7$ isolates were obtained during a survey of 50 Nile river water samples (Rossita Branch), 20 water samples from El-Rahawy Drain and 10 untreated hospital wastewater samples, between June of 2010 and July of 2011. The detection of E. coli $\mathrm{O} 157: \mathrm{H} 7$ was carried out using HiCrome EC O157:H7 selective agar base (HiMedia, India) plates supplemented with novobiocin and potassium tellurite (HiMedia, India). Typical colonies for E. coli $\mathrm{O} 157: \mathrm{H} 7$ were 
confirmed by subculturing on HiCrome MacConky Sorbitol agar base (HiMedia, India) supplemented with tellurite and cefixime (HiMedia, India) and incubated at $37^{\circ} \mathrm{C}$ for $24 \mathrm{~h}$. Indole and oxidase tests [8] were also performed to confirm the $E$. coli $\mathrm{O} 157$ isolates.

\section{Molecular Characterization of $E$. coli O157:H7}

\section{DNA Extraction of E. coli O157:H7 Isolates}

DNA extraction was carried out according to Bai et al. [9]. One colony of each isolate was suspended in one $\mathrm{mL}$ of sterile distilled water and boiled for $10 \mathrm{~min}$ then preserved in ice for $5 \mathrm{~min}$. After centrifugation at $12000 \mathrm{rpm}$ for $10 \mathrm{~min}$, 300-500 $\mu \mathrm{L}$ of the supernatants was transferred to eppendorf tubes, and $5 \mu \mathrm{L}$ of the supernatants was used as templates in multiplex PCR reactions.

\section{Selection and Synthesis of Primers}

The primers used for the multiplex PCR are those listed by Bai et al. [9] targeting six virulence genes of $E$. coli O157:H7: stxl (Shiga toxin 1), stx2 (Shiga toxin 2), eae (intimin), hlyA (hemolysin), $r f b E$ (O157 antigen) and fliC (flagellar antigen) in one microtube. The products sizes of the six virulence genes were at 949, 655, 477, 375, 296 and $199 \mathrm{bp}$ for $f l i C$, stxl, stx2, eae, $r f b E$ and $h l y A$ respectively. Primers for this study were synthesized by Bio-Basic Inc., Canada.

\section{PCR Conditions Optimization}

When multiplex PCR conditions were carried out according to Bai et al. [9] no PCR products were obtained, so different conditions were used to reach an optimal condition. After a series of tests, the reaction conditions were modified to target multiplex genes examined; reaction volume of 50 $\mu \mathrm{L}$ consisting of $5 \mu \mathrm{L}$ of DNA template and $45 \mu \mathrm{L}$ master mix (BioFlux) from $5 \mu \mathrm{L}$ of 10X PCR buffer (containing 7.5 $\mathrm{mM}$ of $\mathrm{MgCl}_{2}, 50 \mathrm{mM}$ of $\mathrm{KCl}, 20 \mathrm{mM}$ of Tris- $\mathrm{HCl}(\mathrm{pH}$ 8.4)), $0.5 \mu \mathrm{L}$ from each primer (mixture of equal amount of the $100 \mathrm{mM}$ primer stocks), $250 \mu \mathrm{M}$ of dNTPs, and 4 units of Taq DNA polymerase (Bio-Rad, CA). The PCR program condition was modified to target multiplex genes examined; $94^{\circ} \mathrm{C}$ denaturation for $3 \mathrm{~min}, 35$ cycles of $94^{\circ} \mathrm{C}$ denaturation for $30 \mathrm{~s}, 60^{\circ} \mathrm{C}$ annealing for $30 \mathrm{~s}, 72^{\circ} \mathrm{C}$ extension for $75 \mathrm{~s}$, and a final step of $72^{\circ} \mathrm{C}$ extension for $5 \mathrm{~min}$. PCR reactions were performed in a TC-S thermal cycler (BOECO, Germany). The amplified DNA was separated on $2 \%$ agarose gel and stained with $0.5 \mu \mathrm{g} / \mathrm{ml}$ of ethidium bromide with Ladder ФX174 DNA/HaeIII digest (TOYOBO, Japan). The DNA bands were visualized and documented with a GelDoc UVP Fluorescent Imaging System (UVP, UK).

\section{Antibiotic Sensitivity of $E$. coli O157:H7 Isolates}

Forty four E. coli $\mathrm{O} 157: \mathrm{H} 7$ isolates and E. coli $\mathrm{O} 157: \mathrm{H} 7$ ATCC 35150 were examined for susceptibility to 6 antibiotics using the Bauer-Kirby disc diffusion method [10]. The following discs (Oxoid, UK) were used for susceptibility test: amoxicillin $10 \mu \mathrm{g}$ (AML 10), cefixime $5 \mu \mathrm{g}$ (CFM 5), ciprofloxacin $5 \mu \mathrm{g}$ (CIP 5), tetracycline $30 \mu \mathrm{g}$ (TE 30), clarithomycin $15 \mu \mathrm{g}$ (CLR 15) and streptomycin $10 \mu \mathrm{g}$ (S 10). The discs used belong to six antibiotic groups: penicillin, $3^{\text {rd }}$ generation cephalosporin, quinolones, tetracycline, macrolides and aminoglycosides, respectively. The tested $E$. coli $\mathrm{O} 157: \mathrm{H} 7$ isolates were cultured on Müller Hinton agar plates and incubated at $37^{\circ} \mathrm{C}$ for $24 \mathrm{~h}$. Isolates were classified as sensitive, intermediate or resistant to each antibiotic according to the National Committee for Clinical Laboratory Standards [11].

\section{RESULTS AND DISCUSSION}

The spread of multiple antimicrobial-resistant pathogenic bacteria has been recognized by the WHO [12] as a serious global human and animal health problem. When manure produced in agriculture is applied to land, pollutants such as antimicrobial compounds, resistant bacteria or resistance genes concentrate and mobilize in soil and often end up in ground or surface water through runoff [13-17]. The development of bacterial antimicrobial resistance is neither an unexpected nor a new phenomenon [18]. E. coli O157:H7 can cause HUS mainly by secretion of Shiga toxins encoded by the genes stxl and/or stx 2 and their variants $[19,20]$. Some antibiotics may cause bacterial lysis and liberate the free Shiga toxins in the intestinal tract [21] or enhance the expression of Shiga toxin genes [22]. Antimicrobial resistance is a natural phenomenon that bacteria use to protect themselves against competitors [23]. The misuse of antibiotics in medicine and agriculture has influenced the frequency and spread of antibiotic resistant bacteria in many aquatic environments $[17,24]$.

In this study, 44 E. coli $\mathrm{O} 157: \mathrm{H7}$ suspected isolates were confirmed by biochemical tests and subjected to the multiplex PCR to detect the six virulence genes in $E$. coli O157:H7. The multiplex PCR results of this work showed that twenty nine out of the $44(66 \%)$ E. coli $\mathrm{O} 157: \mathrm{H} 7$ isolates carried five virulence genes (flic, stxl, stx2, eae and $r f b E)$. Ten out of $44(23 \%)$ carried four virulence genes ( (stxl, stx2, eae and $r f b E)$ in nine isolates and (flic, stx2, eae and $r f b E$ ) in one isolate). In addition to these, five out of 44 $(11 \%)$ carried three virulence genes (stx2, eae and $r f b E)$ (Table 1 and Fig. 1). Bai et al. [9] used the same six primers to test 84 cattle fecal isolates and 57 human clinical isolates of E. coli $\mathrm{O} 157$. The 84 cattle strains differed only in stxl and st $x 2$ genes, and all possessed the other four genes. Among the cattle strains, $28 \%$ had stx $2,26 \%$ had stxl, and $28 \%$ had both $s t x 1$ and stx2. Similarly all the 57 human strains (100\%) possessed $f l i C$, eae, $r f b E$ and $h l y A$ and differed in stxl and $s t x 2$. Of the 57 human strains, $38 \%$ had both stxl and stx2, $60 \%$ had st $x 2$ and only $2 \%$ had stxl alone. In the present study, the hemolysin gene (hly) was not detected in any tested isolates. A possible explanation for that may be that the tested isolates don't carry this gene. Another explanation might be that the amplification process requires further modification.

In Egypt, El-Safey [25] found specific Shiga-like toxin (stxl and stx2), intimin (eaeA) and the enterohemorrhagic $E$. coli hemolysin (hlyA) genes in five E. coli $\mathrm{O} 157: \mathrm{H} 7$ strains isolated from Egyptian food. El-Jakee et al. [26] mentioned that, from the 14 E. coli $\mathrm{O} 157$ strains isolated from different water sources in Egypt and characterized by monoplex PCR eight $(57.1 \%)$ isolates carried stxl and four $(28.6 \%)$ possessed stx2 gene. Intimin (eae), fliCh7 and hly virulence genes were detected in three $(21.4 \%)$, whereas the hly gene was found in four $(28.6 \%)$ of the isolates. 


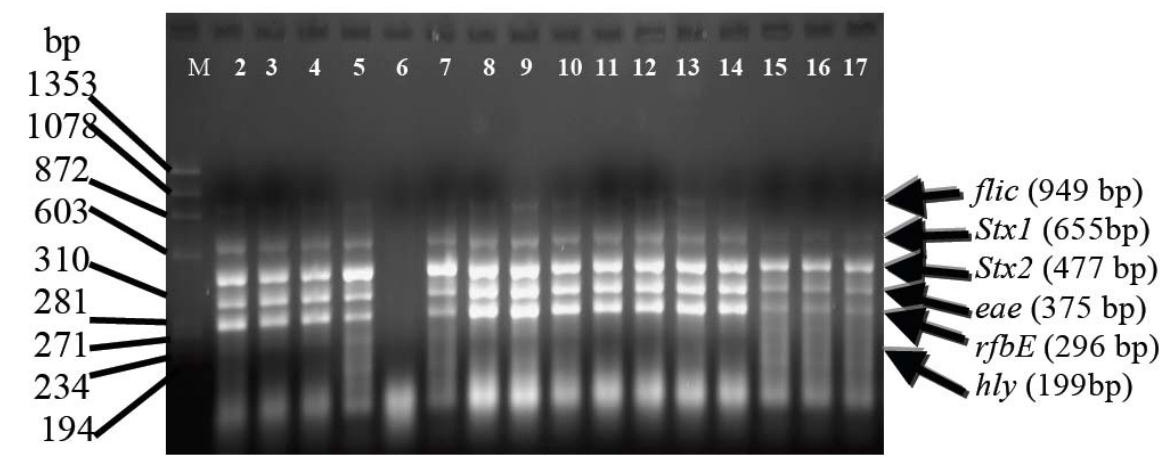

Fig. (1). Multiplex PCR of E. coli O157:H7 isolates from different water samples, Lane M: ФX174 DNA-HaeIII Digest ladder, Lanes 2-5: E. coli O157:H7 isolates Lane 6: negative control, Listeria monocytogenes ATCC 25152 Lane 7-17: E. coli O157:H7 isolates.

Table 1. Antibiotic susceptibility of Shiga toxin producing $E$. coli O157:H7 isolates.

\begin{tabular}{|c|c|c|c|c|c|c|c|c|c|c|c|c|c|c|c|c|c|c|}
\hline \multirow{2}{*}{$\begin{array}{l}\text { No. of Tested Isolates } \\
\text { (44) }\end{array}$} & \multicolumn{3}{|c|}{$\begin{array}{l}\text { Amoxicillin } \\
\text { (AML 10) }\end{array}$} & \multicolumn{3}{|c|}{$\begin{array}{l}\text { Cefaxime } \\
\text { (CFM 5) }\end{array}$} & \multicolumn{3}{|c|}{$\begin{array}{l}\text { Ciprofloxacin } \\
\text { (CIP 5) }\end{array}$} & \multicolumn{3}{|c|}{$\begin{array}{c}\text { Tetracycline } \\
\text { (TE 30) }\end{array}$} & \multicolumn{3}{|c|}{$\begin{array}{l}\text { Clarthromycin } \\
\text { (CLR 15) }\end{array}$} & \multicolumn{3}{|c|}{$\begin{array}{l}\text { Streptomycin } \\
\text { (S 10) }\end{array}$} \\
\hline & $\mathbf{S}$ & I & $\mathbf{R}$ & $\mathbf{S}$ & I & $\mathbf{R}$ & $\mathbf{S}$ & $\mathbf{I}$ & $\mathbf{R}$ & $\mathbf{S}$ & $\mathbf{I}$ & $\mathbf{R}$ & $\mathbf{S}$ & $\mathbf{I}$ & $\mathbf{R}$ & $\mathbf{S}$ & $\mathbf{I}$ & $\mathbf{R}$ \\
\hline $\begin{array}{l}\text { flic, stx 1, stx2, eae, } \\
\qquad r f b E(\mathrm{n}=29)\end{array}$ & - & - & 29 & 24 & 5 & - & 29 & - & - & 27 & - & 2 & - & 4 & 25 & 4 & 22 & 3 \\
\hline $\begin{array}{c}\text { stx } 1, \text { stx2, eae, } r f b E \\
(\mathrm{n}=9)\end{array}$ & - & - & 9 & 9 & - & - & 9 & - & - & 9 & - & - & - & 5 & 4 & - & 8 & 1 \\
\hline $\begin{array}{c}\text { flic, stx2, eae, } r f b E \\
(\mathrm{n}=1)\end{array}$ & - & - & 1 & 1 & - & - & 1 & - & - & 1 & - & - & - & - & 1 & - & 1 & - \\
\hline$s t x 2$, eae, $r f b E(\mathrm{n}=5)$ & - & - & 5 & 4 & 1 & - & 5 & - & - & 4 & 1 & - & - & 1 & 4 & 1 & 3 & 1 \\
\hline
\end{tabular}

In the present study, all E. coli $\mathrm{O} 157: \mathrm{H} 7$ isolates (44) were found to be resistant to amoxicillin (100\%). Fewer isolates were resistant to clarithomycin (77\%), streptomycin (11\%) and tetracycline (7\%). Moreover, E. coli O157:H7 isolates showed sensitivity to ciprofloxacin (100\%), tetracycline (93\%) and cefaxime (86\%) (Table 1). Maal-Bared et al. [27] examined the distribution of antibiotic resistant $E$. coli and $E$. coli $\mathrm{O} 157$ isolated from water, sediment and biofilms in an intensive agricultural watershed. They found that the frequency of resistance of E. coli and E. coli $\mathrm{O} 157$ to ampicillin, cefotaxime, nalidixic acid and tetracycline was significantly different among sampling sites. Also, Edge and Hill [28] found low levels of resistance to ciprofloxacin. High levels of resistance to ampicillin were expected due to fact that ampicillin are older antibiotics that have been extensively used over the years [29].

In this study, the difference between the E. coli $\mathrm{O} 157: \mathrm{H} 7$ ATCC 35150 reference strain and the environmental isolates was in the sensitivity to streptomycin. While the ATCC strain was sensitive to streptomycin, the environmental isolates showed intermediate sensitivity $(75 \%)$ to streptomycin (Table 1). In many studies, e.g. Edge and Hill [28] and Wat- kinson et al. [30] the antimicrobial resistance of E. coli isolated from water to a variety of antibiotics has been shown. Moreover, isolation of resistant E. coli $\mathrm{O} 157$ from multiple aquatic ecosystems has been reported [30]. The frequency of resistance was highest to tetracycline, followed by ampicillin and streptomycin. High levels of E. coli antibiotic resistance to tetracycline and ampicillin have been observed in many other studies [30-32]. Maal-Bared et al. [27] concluded that, there are strong relationships between the water quality and antimicrobial resistance. Furthermore, E. coli is a microorganism that is proficient at horizontal gene transfer that could transmit its resistance genes to other facultative or obligate pathogenic bacteria.

CDC's National Antibiotic Resistance Monitoring System (NARMS) have found widely varying levels of antibiotic resistance among E. coli 0157 serotypes, with $10 \%$ of the E. coli $\mathrm{O} 157$ isolates being resistant to one or more antibiotics, and 7\% being multidrug resistant [3]. A study focusing on isolates from cattle, humans, swine and farms found that $39 \%$ of the E. coli isolates were resistant to one or more antimicrobials [4]. 
Finally, it can be concluded that, due to abuse and misuse of antibiotics, environmental E. coli $\mathrm{O} 157: \mathrm{H} 7$ strains develop strategies for resistance more than reference strains, thus, restriction of antibiotics used must be enforced. Also, more investigations are required to find the correlation, if any, between the presence of pathogenic bacteria virulence genes and resistance to antibiotics. Moreover, it is very important to monitor the prevalence and persistence of $E$. coli O157:H7 organisms in aquatic environment from time to time.

\section{According to NCCLS 2007 [11]}

R: Resistant (AML 10 and CLR $15 \leq 13 \mathrm{~mm}$; CFM 5 and CIP $5 \leq 15 \mathrm{~mm}$; TE 30 and $\mathrm{S} 10 \leq 11 \mathrm{~mm}$ ).

I: Intermediate (AML 10 14-16mm; CFM 5 16-18mm; CIP 5 16-20mm; TE 30 and S10 12-14mm; CLR 15 14$17 \mathrm{~mm})$.

S: Sensitive (AML $10 \geq 17 \mathrm{~mm}$; CFM $5 \geq 19 \mathrm{~mm}$; CIP $5 \geq$ $21 \mathrm{~mm}$; TE 30 and $\mathrm{S} 10 \geq 15 \mathrm{~mm}$; CLR $15 \geq 18 \mathrm{~mm}$ ).

\section{CONFLICT OF INTEREST}

The authors confirm that this article content has no conflict of interest.

\section{ACKNOWLEDGEMENTS}

Declared none.

\section{REFERENCES}

[1] Chalmers RM, Aird H, Bolton FJ. Waterborne Escherichia coli O157. Appl Microbiol 2000; 88: 124-32.

[2] Elder RO, Keen JE, Siragusa ER, Barkocy-Gallagher GA, Koohmaraie M, Laegreid WW. Correlation of enterohemorrhagic Escherichia coli $\mathrm{O} 157$ prevalence in feces, hides and carcasses of beef cattle during processing. Proc Natl Acad Sci USA 2000; 97 : 2999-3.

[3] NARMS. National Antibiotic Resistance Monitoring System for Enteric Bacteria. CDC 2000 Ref Type: Generic.

[4] Schroeder CM, Zhao C, Debroy C, et al. Antimicrobial resistance of Escherichia coli $\mathrm{O} 157$ isolated from humans, cattle, swine, and food. Appl Environ Microbiol 2002; 68: 576-81.

[5] Galland JC, Hyatt DR, Crupper SS, Acheson DW. Prevalence, antibiotic susceptibility, and diversity of Escherichia coli O157:H7 isolates from a longitudinal study of beef cattle feedlots. Appl Environ Microbiol 2001; 67: 1619-27.

[6] Solomakos N, Govaris A, Angelidis AS, et al. Occurrence, virulence genes and antibiotic resistance of Escherichia coli O157 isolated from raw bovine, caprine and ovine milk in Greece. Food Microbiol 2009; 26: 865-71.

[7] Olatoye IO, Olufemi I. The incidence and antibiotics susceptibility of Escherichia coli O157:H7 from beef in Ibadan Municipal, Nigeria. Afri J Biotechnol 2010; 9: 1196-9.

[8] APHA (American Public health Association). Standard methods for the examination of water and wastewater, $21^{\text {st }}$ ed. Washington, D.C: Technology and Engineering, 2005

[9] Bai J, Shi X, Nagaraja TG. A multiplex PCR procedure for the detection of six major virulence genes in Escherichia coli O157:H7. Microbiol Meth 2010; 82: 85-9.

[10] Bauer AW, Kirby WM, Sherris JC, Turck M. Antibiotic susceptibility testing by a standardized single disk method. Am J Clin Pathol 1966; 45: 493-6.
[11] NCCLS. (National Committee for Clinical Laboratory Standards). Performance Standard for Antimicrobial Susceptibility Testing; Seventeenth Informational Supplement. This Standard Contains the current Clinical and Laboratories Standards Institute guidelines (CLSI)- recommended Methods for disk susceptibility testing, criteria for quality control testing, and updated tables for interpretive zone diameter 2007; M100-S17.

[12] WHO (World Health Organization). Drinking Water Quality Series, Paris, France: OECD-WHO, 2003.

[13] Hirsch R, Ternes T, Haberer K, Kratz KL. Occurrence of antibiotics in the aquatic environment. Sci Total Environ 1999; 225: 10918.

[14] Chee-Sanford JC, Aminov RI, Krapac IJ, Garrigues-Jeanjean N, Mackie RI. Occurrence and diversity of tetracycline resistance genes in lagoons and groundwater underlying two swine production facilities. Appl Environ Microbiol 2001; 67: 1494-502.

[15] Pedersen J, Yeager M, Suffet I. Xenobiotic organic compounds in runoff from fields irrigated with treated wastewater. J Agric Food Chem 2003; 51: 1360-72.

[16] Duriez P, Topp E. Temporal dynamics and impact of manure storage on antibiotic resistance patterns and population structure of $E s$ cherichia coli isolates from a commercial swine farm. Appl Environ Microbial 2007; 73: 5486-93.

[17] Ribeiro AF, Laroche E, Hanin G, Fournier M, Quillet L, Dupont JP. Antibiotic-resistant Escherichia coli in karstic systems: a biological indicator of the origin of fecal contamination. FEMS Microbiol Ecol 2012; 81: 267-80.

[18] OIE (Terrestrial Manual). Laboratory methodologies for bacterial Antimicrobial susceptibility testing, 2008; Chapter Book 1.1.6. pp. 56.

[19] Karmali MA. Infection by verocytotoxin-producing Escherichia coli. Clin Microbiol Rev 1989; 2: 15-38

[20] Pierard D, Muyldermans G, Moriau L, Stevens D, Lauwers S. Identification of new verocytotoxin type 2 variant B-subunit genes in human and animal Escherichia coli isolates. J Clin Microbiol 1998; 36: 3317-22.

[21] Wong CS, Jelacic S, Habeeb RL, Watkins SL, Tarr PI. The risk of the hemolytic-uremic syndrome after antibiotic treatment of Escherichia coli O157:H7 infections. N Engl J Med 2000; 342: 19306.

[22] Zhang X, McDaniel AD, Wolf LE, Keusch GT, Waldor MK, Acheson DW. Quinolone antibiotics induce Shiga toxin-encoding bacteriophages, toxin production, and death in mice. J Infect Dis 2000; 181: 664-70.

[23] Kümmerer K. Resistance in the environment. J Antimicrobial Chemother 2004; 54: 311-20.

[24] Laroche E, Petit F, Fournier M, Pawlak B. Transport of antibioticresistant Escherichia coli in a public rural karst water supply. J Hydrol 2010; 392: 12-21.

[25] El-Safey MS. Search for E. coli O157:H7 in Egyptian foods and dairy products. Ph. D. Thesis, Cairo, Egypt: Botany and Microbiology Department, Faculty of Science Al-Azhar University 2001.

[26] El-Jakee J, El-moussa K, Mohamed F, Mohamed G. Using molecular techniques for characterization of $E$. coli isolated from water sources in Egypt. Glob Veterinaria 2009; 3: 354-62.

[27] Maal-Bared R, Bartlett KH, Bowie WR, Hall E. Phenotypic antibiotic resistance of Escherichia coli and E. coli $\mathrm{O} 157$ isolated from water, sediment and biofilms in an agricultural watershed in British Columbia. Sci Tot Environ 2013; 443: 315-23.

[28] Edge TA, Hill S. Occurrence of antibiotic resistance in Escherichia coli from surface waters and faecal pollution sources near Hamilton Ontario. Can J Microbiol 2005; 51: 501-15.

[29] Rooklidge SJ. Environmental antimicrobial contamination from terraccumulation and diffuse pollution pathways. Sci Tot Environ 2004; 325: 1-13

[30] Watkinson AJ, Micalizzi GB, Graham GM, Bates JB, Costanzo SD. Antibiotic-resistant Escherichia coli in wastewaters, surface waters, and oysters from an urban river system. Appl Environ Microbiol 2007; 73: 5667-70.

[31] Hamelin K, Bruant G, El-Shaarawi A, et al. Occurrence of virulence and antimicrobial resistance genes in Escherichia coli isolates 
from different aquatic ecosystems within the St. Clair River and Detroit River areas. Appl Environ Microbiol 2007; 73: 477-84.
[32] Mudryk Z, Perlinski P, Skorczewski P. Detection of antibiotic resistant bacteria inhabiting the sand of non-recreational marine beach. Mar Pollut Bull 2010; 60: 207-14.

Received: October 16, 2014

Revised: January 04, 2015

Accepted: June 03, 2015

(C) El-Shatoury et al.; Licensee Bentham Open.

This is an open access article licensed under the terms of the Creative Commons Attribution Non-Commercial License (http://creativecommons.org/licenses/by-nc/3.0/) which permits unrestricted, non-commercial use, distribution and reproduction in any medium, provided the work is properly cited. 